\title{
港湾構造物のライフサイクル管理
}

\author{
善一 一 章* \\ *国際航路協会 WG31 メンバー

\section{Life Cycle Management of Port Structures} \\ Kazuaki Zen* \\ * PIANC PTC-II WG31 Member
}

\begin{abstract}
Port authorities are interested in the behavior of the civil engineering elements of port infrastructure, particularly with respect to the financial, technical, safety and environmental decisions to be taken during the life-time of the structures. It therefore follows that to avoid unexpected large-scale rehabilitation measures as a consequence of neglected periodic maintenance, a systematical planning and budgeting of maintenance activities is necessary. Life Cycle Management (LCM), and its precursor Whole Life Costing (WLC), will contribute to a realistic approach of maintenance policy, including decision-making, planning, budgeting and funding of inspection and repair activities during the life-time of port structures.

PIANC PTC-II Working Group 31 (WG31) was constituted in 1993 to review and offer guidance on the use of LCM for new and existing structures in ports and published the LCM Report in 1998. In accordance with the LCM Report, the significance and outline of LCM, the outline and example of WLC and the case study of LCM are presented.
\end{abstract}

Key words : PIANC, LCM, WLC, discount rate, present worth factor, concentrated corrosion, low water level corrosion, corrosion damage, salt induced corrosion.

\section{1.は じめに}

日本では, 1970 年代〜1980 年代にかけて, 港湾構造 物の腐食調查が旧運輸省港湾技術研究所（現：独立行政 法人 港湾空港技術研究所）を中心として行われた。調 查の結果, 港湾鋼構造物（鋼矢板, 鋼管杭など）では, 特定部位に発生する集中腐食のために, 比較的短期間で 使用不能となるケースのあることがわかった1)。特に， 平均干潮面付近の損傷が著しい. また, 海水面上に暴露 する鉄筋コンクリート部材では, 塩害のため早期劣化が 発生した ${ }^{2)}$. 鋼構造物の集中腐食や鉄筋コンクリート部 材の塩害は海外の港湾構造物でも同様に発生している. (3 章参照).

集中腐食や塩害による損傷の結果, 比較的短期間で構 造物の大規模な補修が必要となる。これは定期的なメン テナンスを念ったためで, 著しい場合には, 港湾管理者 は，補修費のほかに補修期間中の施設の閉鎖による莫大 な経済的損失を蒙る。このような経済的損失を避けるに は, メンテナンス活動の組織的計画と予算措置を伴うラ イフサイクル管理 (LCM) が必要となる.日本では, 20 世紀後半に建設された構造物の老朽化が進み, 21 世紀に は社会資本ストックの維持管理が重要な問題と認識さ れ，最適な管理を行って所定の性能と安全性を保持し， 財政負担を最小化する社会資本ストックの LCM の必要 性が提唱されている．港湾の分野でも港湾構造物のスト ックが膨大であり (20 数兆円ともいわれる)，これらスト ックの効率的な維持管理が重要な問題である. 海外でも

* ₹ 213-0011 川崎市高津区久本 3-6-1-401（3-6-1-401, Hisamoto, Takatsuku, Kawasaki, 213-0011 Japan)
腐食損傷の発生から, 港湾構造物の維持管理の必要性が 認識されている.

港湾構造物の LCM の必要性は各国共通であるから, 国際航路協会の技術部会 WG31 で港湾構造物の LCM を 検討した。本報では, PIANC PTC-II WG31 報告を参照し て, 2 章 PIANC PTC-II WG31，3 章 海外における腐食損 傷傾向, 4 章 LCM サイクルとホールライフコスティン グ (WLC)，5 章 WLC の適用例，6 章 LCM による維持管 理例を紹介する。

\section{PIANC PTC-II WG31}

国際航路会議協会 (Permanent International Association of Navigation Congress : PIANC) は, 近世以来, 河 川や運河を利用した内陸水運の発達したヨーロッパで, 円滑かつ効率的な交通・交易のために国際間の協議が必 要となり 1885 年に設立された団体で，国連の諮問機関 にも指定されている. ベルギー国ブリュッセルに本部を 置き, 当初は内陸水路・内陸港を検討の対象としたが, 1898 年から海洋港も検討の対象として扱うようになっ た. 参加国は日本を含めて 67 か国である。各種委員会 の中, 必要テーマの研究活動を行う常設技術委員会 (Permanent Technical Committee : PTC)I, II がある. PTC-I は内陸水路及び内陸港を, PTC-II は海洋港を担当 する.1999年に国際航路会議協会から国際航路協会 (International Navigation Association) に改名され, 同時 に, PTC-II は MarCom (Marine Navigation Committee) に変更された。ただし，略称の PIANC はこれまで通り 使用することになったので，ここでは，国際航路協会を 従来通りPIANC と呼ぶことにする.

WG31 は PTC-II の 31 番目のワーキンググループで, 
前期作業（1993～1998）では，港湾構造物の LCM を検討した。前期報告 “港湾構造物の LCM : 一般 原理” ${ }^{3)}$ は 1998 年に発刊され, その内容は, LCM の 定義, LCM を行う理由, ホールライフコスティン グ (WLC), LCM 実施の概要, LCM システムの設定 と運用指針，推奨，ケーススタディ，参考文献であ る. 後期作業（1998～2002）では，10 年前に発刊さ れたWG17 報告（塩水環境における材料劣化：1990） を改訂した。後期報告（未刊）の内容は “港湾構造 物の点検・維持・補修”4)である。後期報告では前期 報告を LCM 報告という．本報でも同様に前期報告 を LCM 報告と呼ぶことにする．なお，WG31 の構 成は, 11 か国 18 名である.

\section{3. 海外における腐食損傷傾向}

海外における港湾構造物の腐食による損傷傾向は, 日 本の港湾構造物の損傷傾向1), 2) に類似している.すなわ ち, 鋼構造物では, 飛沫帯は飛沫帯腐食によって損傷し, 平均干潮面直下付近では集中腐食が発生している。 また, 漂砂のある海域では海泥面に集中腐食が発生している. ヨーロッパでは, 平均干潮面付近に発生する集中腐食を 干潮面腐食 (low water level corrosion) と呼んでいる。 ま た，海水面上に暴露する鉄筋コンクリート部材では，塩 害が発生している。

腐食による経済的損失は，例えば，構造物の維持管理 を怠ったために補修が必要となり，補修費（直接費） 2 万ドル，補修時の施設閉鎖による経済的損失（間接費） 150 万ドルであった．施設閉鎖による大きな経済的損失 の発生によって, 当該港の関係者は改めて LCM の必要 性を痛感した。

図 1 に, 北西ヨーロッパ（イギリス・フランス・ベル ギー・オランダ・ドイッ・デンマーク）において干潮面 腐食が発生した港の位置（黒三角印）を示す5). 図 1 に 示すように，干潮面腐食はヨーロッパ各国で発生してい る.このほか, 干潮面付近に扮ける集中腐食はアメリカ などでも発生している．図 2 にスウェーデンにおける腐 食調查港の位置を示す ${ }^{6)}$. スウェーデン各港における最 大腐食速度は干潮面付近で $0.2 \mathrm{~mm} / \mathrm{yr} \sim 0.4 \mathrm{~mm} / \mathrm{yr}$ であ った。北欧では，干潮面腐食の発生因として，氷の接触 や船のプロペラによる高流速 $(1.5 \mathrm{~m} / \mathrm{s})$ の海水噴射など をあげている．これは，集中腐食の発生因が衝突・磨耗 などによるさび層除去に依存することを示している，腐 食調査港では，干潮面腐食によって発生した鋼矢板の穴 が凸矢板の，例えば，角部にあき，穴から裏込め土砂が 流出して空洞化した。このような現象は日本の鋼矢板構 造物でも見られる。鋼矢板防砂堤では，漂砂により海泥 面のさび層が除去された箇所の腐食速度は約 $3 \mathrm{~mm} / \mathrm{yr}$ で, $9 \mathrm{~mm}$ 厚の鋼矢板が 3 年足らずで切断状態になった 例がある7). また，栈橋上部工の鉄筋コンクリート部材 の塩害が各国で発生しており，塩害による損傷は港湾構 造物損傷の一因である2).

\section{4. ライフサイクル管理 (LCM)}

3 章に示すように，港湾構造物は腐食による損傷が不

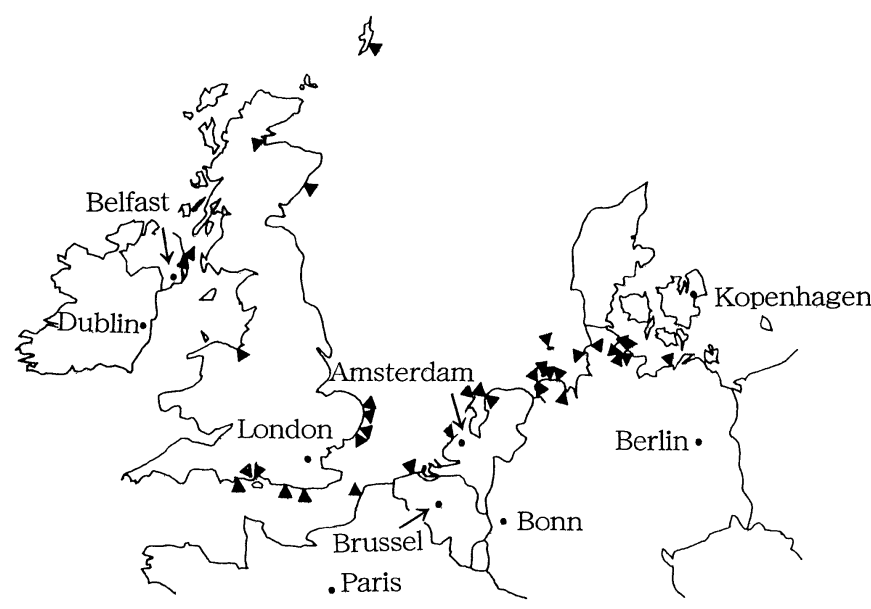

図 1 北西ヨーロッパにおける干潮面腐食の発生位置

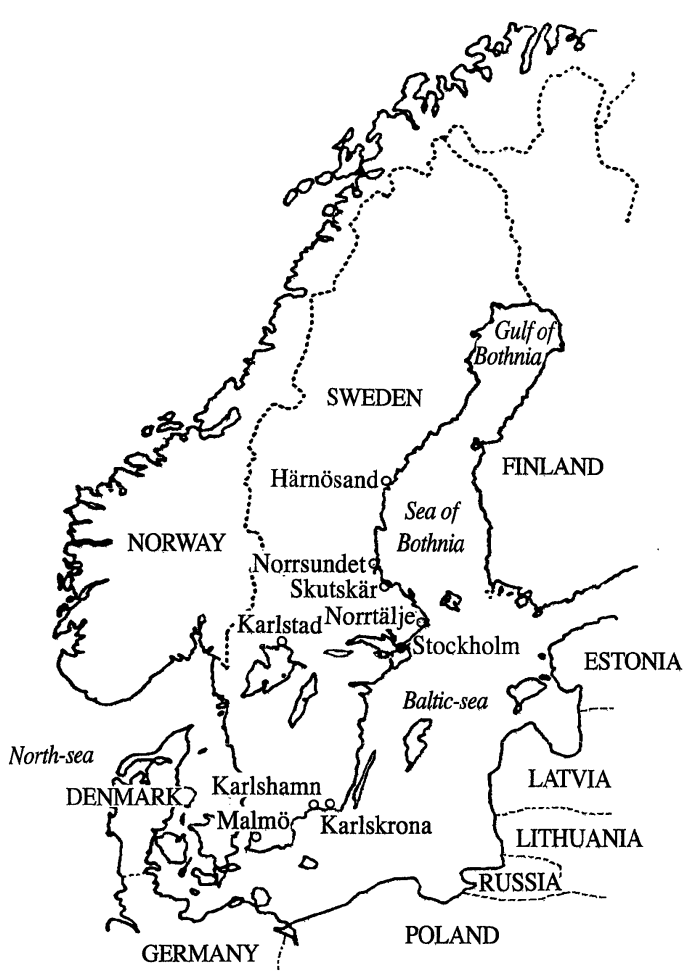

図 2 スウェーデンにおける腐食調査位置

可避であり，特に集中腐食による損傷が短期間で著しい. この結果, 日本では, 港湾鋼構造物は仮設物を除いて原 則として技術基準に準拠して防食するように技術マニュ アルが改訂された ${ }^{8)}$. 一方, 各国における港湾構造物の 維持管理が十分に行われているとはいい難く, むしろ構 造物が損傷してから対策がとられている．また，維持管 理や補修工事の際，公共施設の閉鎖はできるだけ避ける ことが望まれ，ライフサイクルコストを安くするには直 接費（補修費合計）のコストダウンのほか，間接費（閉 鎖に伴う損失費合計）をできるだけなくすことが必要で ある。これに対して，LCM システムの目的は，寿命期 間を通じて港湾構造物の維持管理を容易にするために， 費用対効果のある実用的なシステムをオーナーに提供す ることである.

LCM には，財政上・技術上・安全上の局面がある. 
港湾構造物の維持管理に関する技術上と安全上の課題に ついては, なお検討を要する項目もあるが, 大半は技術 マニュアル ${ }^{8}$ が利用できる，ただし，技術マニュアルの 利用に際しては，LCM の観点からの配慮が必要である. 経済評価については，技術マニュアルでは，“経済性の 優れた工法を採用する”, “経済性を検討して工法を選定 する”などのように定性的に述べてあるに過ぎない。ま た, 一般には, 経済比較は単に初期コストで行われてい る. 従って, LCM の財政上の課題として, ライフサイ クルコストを用いて経済比較を定量的に行う LCM シス テムの適用が望まれる. 本章では, $4.1 に \mathrm{LCM}$ サイクル, 4.2 にCM における経済的比較手法である WLC につい て述べる.

\subsection{LCM サイクル}

LCM サイクルには, 計画・設計一建設一稼働一撤去 の 4 段階がある. 維持点検（点検・補修・補強）は，新 設構造物では計画・設計の段階から考慮し, 既設構造物 では稼動の段階で検討する，構造物が規則的な稼働に入 っている時, LCM システムは図 3 のように循環する. 図 3 では，データベース（6.2）が LCM サイクルの中心 に位置する．収集した情報と実施した措置はすべてデー タベースに記録する. LCM に関する分析, 決定, 措置 は, すべてデータベースからの情報に基づく，定期点検 (6.3.2) の結果を解析 (6.4) し, 必要な改善作業を計画す る. 特別点検が不要ならば, 図中の下線を経由して次の 定期点検 (6.3.2) に戻る. 問題があれば, 報告書をオー ナーに提出する．報告書はオーナーの検討と対策決定に 役立つ (6.5). 特別の決定をする時, 更に必要な措置と 維持補修の適用性を検討するために, 特別点検 (6.3.3) ・メンテナンス補修 (6.6) を行う. 特別点検に基づく作 業終了後, 次の定期点検に戻る. 循環におけるすべての 主要措置は, データベース（6.2）に記録する。なお，( ) 内の数字は WG31 の LCM 報告 ${ }^{3)}$ の章・節を示す。（注 1：ヨーロッパでは民営化の港湾施設が多いので, LCM 報告では，上記のように“オーナー”という表現が使用 されている.)

\section{2 ホールライフコスティング (WLC)}

WG31 後期報告4)では, LCM 報告3)を参照して WLC の手法でコスト比較を定量的に行うことを提案してい る.ライフサイクルコストの算定と比較手法をヨーロッ パの例にならって LCM 報告ではホールライフコスティ ング (WLC) と呼ぶ. WLC は港湾の分野では必ずしも使
用されていないが，最近一般的となってきた手法である. WLC は, 構造物の寿命期間の全コスト（=直接費 +間 接費）を查定するもので, 計画されたプロジェクトの事 前評価に使用される。すなわち，この評価によって，管 理者は限られた予算に対して競争するプロジェクト間の 合理的な決定ができる．また，管理者は初期コストを多 くして将来のメンテナンスコストを少なくするか, 反対 に初期コストを少なくして将来のメンテナンスコストを 多くするかの支出レベルの選択が可能となる.

経済分析では，お金の時間価值を考慮するのが基本で ある。お金の時間価值を考慮して経済分析する基礎的方 法として, 現在価值 (PW) 法, 将来価值 $(\mathrm{FW})$ 法, 年間 価值 $(\mathrm{AW})$ 法がある. LCM 報告では WLC に PW 法を使 用する。 PW 法は, 式 (1) から, 減価率を用いて既知の 将来価值 $(\mathrm{F})$ から現在価值（P）を求める.

$$
\mathrm{P}=\mathrm{F}(1+\mathrm{r})^{-\mathrm{N}}
$$

ここで, P : 現在価值 (present worth)

$\mathrm{F}$ : 将来価值 (future worth)

$\mathrm{r}$ : 減価率 (discount rate)

$\mathrm{N}$ : 複利期間 (年)

(number of compounding periods)

$(1+r)^{-\mathrm{N}}$ : 現在価值係数 (present worth factor)

式 (1) では, 所定の減価率 (r) に対して, それが発生 する時点で計算した $(\mathrm{P})$ は, それが発生する時点での既 知量 $(\mathrm{F})$ に等価值である，すなわち，Fに交換できる. 減価率を用いて, 現時点での等価値へ変換する方法を現 在価值法という。 また, 現在価値 $(\mathrm{P})$ は, 将来関わり合 いのある金額に関する利益の累積を考慮して，すべての 終局コストに合致するように貯えておく金額とも言え る. 一般に, 減価率が大きい時, 将来のメンテナンスコ ストは無視できるようになるので，初期コストを小さく する傾向である. 反対に, 減価率が小さい時, 将来のメ ンテナンスコストが無視できなくなるので，初期コスト を大きくする傾向である，減価率は各国で異なり，アメ リカでは $10 \%$ ，イギリスでは $8 \%$ ，ドイッでは $3 \%$ ，ス イスでは $2 \%$ ある。 オプションの選定に WLCを適用 する時, 現在価值が最小のオプションが最適であると判 定する.なお, WLC の結果は絶対的ではなく相対的で あり，各種パラメー夕の傾向または順位のみを与える. WLC の使用によって将来コスト（メンテナンスコスト や撤去コストなど）が設計の段階で検討できる利点があ る．港湾構造物の維持管理に LCM を適用するには，ラ イフサイクルコストの算定が必要となる. 防食データに 関しては防食技術者のノウハウが求められる.（注 $2 ：$ 公

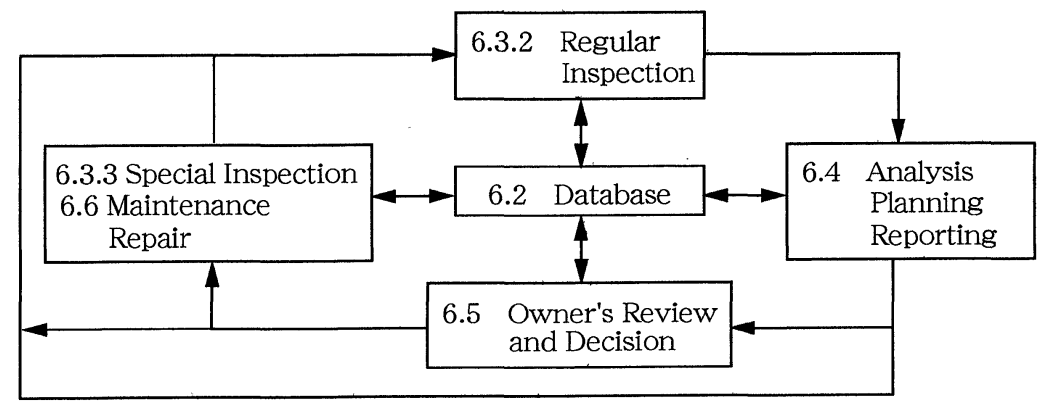

図 3 LCM の定期作業 
共プロジェクトの評価に $\mathrm{B} / \mathrm{C}$ 法が使用される．B (便益) と C (コスト) には，一般に，PW 值が使用される。 $\mathrm{B} / \mathrm{C}$ 法では, $\mathrm{B} / \mathrm{C}>1.0$ または $\mathrm{B} / \mathrm{C}=1.0$ の場合, プロジェク トの建設は有意であると判定する. B/C 法における社会 便益の算定はコスト算定に比べて難しい. なお， $\mathrm{B} / \mathrm{C}$ 法 での減価率は，日本における適用例では，一般に，4\% を使用している.)

オーナーは, 契約形式にかかわらず設計・建設の発注 前に自分の要求をWLC によって明確にすることができ る. 従って, オーナーはWLC の検討を押し進め, 検討 するための資金を配分する必要がある.

技術者は, WLC に関係する項目の数量化が求められ る。例えば，各種計画案のコスト比較，耐久性に関する 比較設計, 点検とメンテナンス, 将来の施設撤去, 短期 部材の計画許容, 性能プロフィルの明確化などである. また, メンテナンスマニュアルの整備も必要である.

LCM では，公的または民間施設にかかわらず，メン テナンス管理が必要である.メンテナンス管理者の役割 には，点検体制，補修・取替元計画，中期補修の予算化， 耐久性に関するデータベース，廃棄または再建に対する 長期計画などの検討がある.

\section{WLC の適用例}

LCM 報告の WLC 適用例は, 新鉱山輸出栈橋の計画段 階における二つの設計オプションのライフサイクルコス トを比較する. 単純化したオプションのパラメータは以 下の通りである.

・環境：熱帯

・建設費：オプション $1 ： \$ 12 \mathrm{M}$ オプション $2: \$ 18 \mathrm{M}$

・鉱山の期待寿命 $: 50$ 年

・輸出する鉱石の商品価值は $\$ 40 /$ トンである．年間輸 出高は 0 年 $~ 8$ 年では 8 百万トン, 9 年〜 50 年では 12 百万トンである。

・施設閉鎖による損失 : 0 年 8 年では $\$ 1.84 \mathrm{M}, 9$ 年〜 50 年では $\$ 2.72 \mathrm{M}$ である.

・メンテナンスコスト (\$M/年) :

$\begin{array}{cccc}\text { 年 } & \text { オプション } & \text { 年 } & \text { オプション } 2 \\ 0 \sim 7 & 0 & 0 \sim 12 & 0 \\ 8 \sim 14 & 1.5 & 13 & 2.5 \\ 15 \sim 19 & 1.0 & 18 & 2.0 \\ 20 \sim 27 & 0.2 & 23 & 2.5 \\ 28 \sim 34 & 0.5 & 28 & 2.5 \\ 35 \sim 39 & 0.2 & 33 & 2.0 \\ 40 \sim 44 & 1.0 & 38 & 2.0 \\ 45 \sim 50 & 0 & 43 & 2.5 \\ & & 45 \sim 50 & 0\end{array}$

・係船岸の撤去費 : オプション $1: \$ 4 \mathrm{M}$ オプション $2: \$ 5 \mathrm{M}$

・減価率 : $3 \%$ と $8 \%$

評価結果

(1) オプション 1,2 の現在価値コストを, 図 4(減価 率 $3 \%$ ） と図 5 （隇価率 $8 \%$ ）に示す。

（2）ホールライフコストは, 次の通り：

$\begin{array}{ccc} & \text { 滅価率 } 3 \% & \text { 隇価率 } 8 \% \\ \text { オプション } 1 & \$ 73 \mathrm{M} & \$ 36 \mathrm{M} \\ \text { オプション } 2 & \$ 36 \mathrm{M} & \$ 24 \mathrm{M}\end{array}$

この結果, 減価率 $3 \%$ と $8 \%$ ともオプション 2 の 方が有利である。なお，ホールライフコスト差は， 減価率 3\%に比べて減価率 $8 \%$ の方が接近している.

(3) 従って, 減価率 $8 \%$ では, パラメー夕の数值変化, または他のパラメータの導入によって選択が変わる ことが予想される，例えば，オプション 1 の熱带環 境 $(7$ 年間補修の必要がない) を温和な環境 $(20$ 年 間補修の必要がない）と仮定して，これをオプショ ン (1) とする.オプション(1) のホールライフコス トは, 次の通り :

$\begin{array}{ccc} & \text { 減価率 } 3 \% & \text { 隇価率 } 8 \% \\ \text { オプション (1) } & \$ 41 \mathrm{M} & \$ 19 \mathrm{M}\end{array}$
ホールライフコストは, 減価率 $8 \%$ ではオプショ ン(1)の方が有利となる (図 5 参照).

(4) オプション 2 の施設閉鎖日数は, オプション 1 の施設閉鎖日数の約 $1 / 5$ である. 減価率 $3 \%$ の時の 直接費 (補修費) と間接費（閉鎖に伴う損失）は， 次の通り：

$\begin{array}{llc} & \text { 直接費 } & \text { 間接費 } \\ \text { オプション } 1 & \$ 15.5 \mathrm{M} & \$ 45.7 \mathrm{M} \\ \text { オプション } 2 & \$ 8.5 \mathrm{M} & \$ 9.7 \mathrm{M}\end{array}$

ライフサイクルコストを減少するには, 直接費の みでなく間接費が小さい工法が望ましい。

（5）栈橋の建設期間が鉱山開設の支配的要因であれ

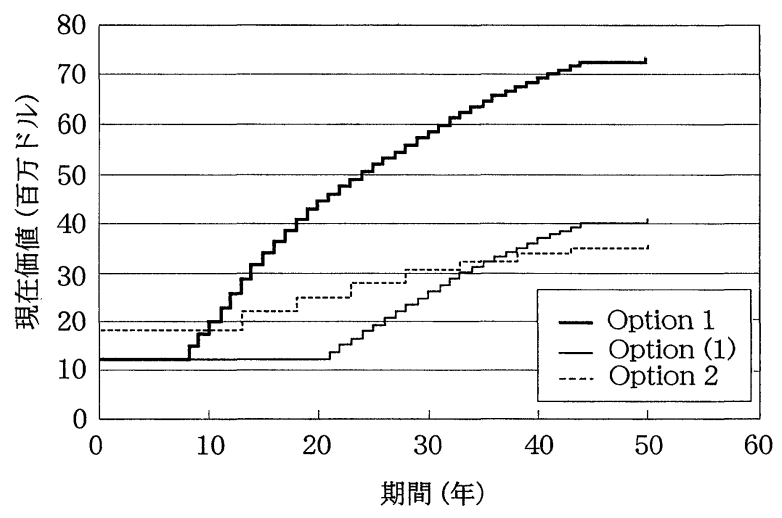

図 4 オプション 1, (1), 2 の現在価值コスト（減価率 $3 \%)$

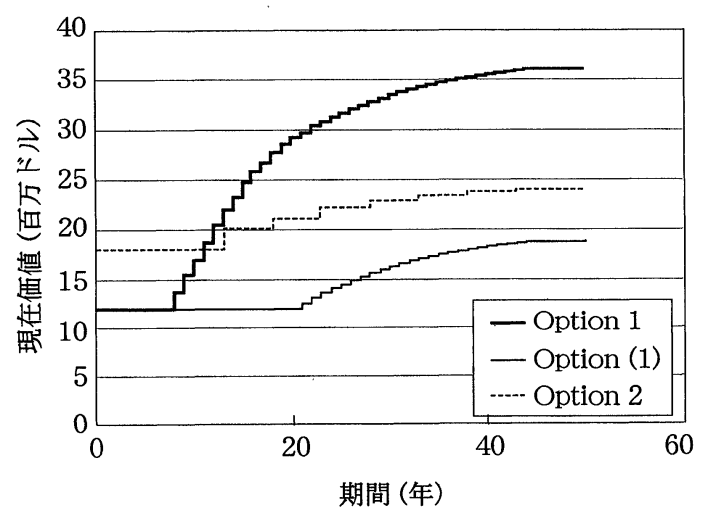

図 5 オプション 1, (1), 2 の現在価值コスト（減価率 $8 \%$ ) 
表 1 点検プログラム（ストックホルム旧港）

\begin{tabular}{|c|c|c|c|c|c|c|c|c|c|c|c|c|c|}
\hline \multirow{3}{*}{$\begin{array}{c}\text { 岸 } \\
\text { 壁 } \\
\text { No. }\end{array}$} & \multirow{3}{*}{$\begin{array}{c}\text { 岸壁長 } \\
(\mathrm{m})\end{array}$} & \multicolumn{2}{|c|}{ 目視点検 } & \multicolumn{2}{|c|}{ 潜水点検 } & \multicolumn{2}{|c|}{ 水深測量 } & \multicolumn{2}{|c|}{$\mathrm{TP} \cdot \mathrm{W}$} & \multirow{2}{*}{\multicolumn{3}{|c|}{$\begin{array}{c}\text { 材料試験 } \\
\text { 年 }\end{array}$}} & \multirow[t]{3}{*}{ 注 } \\
\hline & & \multirow[t]{2}{*}{ 年 } & \multirow{2}{*}{$\begin{array}{l}\text { 間隔 } \\
\text { (年) }\end{array}$} & \multirow[t]{2}{*}{ 年 } & \multirow{2}{*}{$\begin{array}{l}\text { 間隔 } \\
\text { (年) }\end{array}$} & \multirow[t]{2}{*}{ 年 } & \multirow{2}{*}{$\begin{array}{l}\text { 間隔 } \\
\text { (年) }\end{array}$} & \multirow[t]{2}{*}{ 年 } & \multirow[t]{2}{*}{ 注 } & & & & \\
\hline & & & & & & & & & & ב & 鋼 & 木 & \\
\hline 1 & 245 & 98 & 10 & '98 & 10 & 98 & 10 & 08 & W & '08 & & '98 & \\
\hline 2 & 127 & 98 & 5 & '98 & 5 & '98 & 5 & '98 & $\mathrm{TP}^{1)}$ & & & '98 & 1)控え工 \\
\hline 3 & 167 & 97 & 10 & 97 & 10 & 97 & 10 & 98 & $T P^{1)}$ & & & & 1)控え工 \\
\hline 4 & 113 & 97 & 10 & 97 & 10 & 97 & 10 & 95 & W & 95 & & & \\
\hline 5 & 313 & 96 & 5 & 96 & 5 & 96 & 10 & '96 & W & 96 & & & \\
\hline 6 & 45 & 96 & 10 & 96 & 10 & 96 & 10 & ’06 & $\mathrm{TP}^{1)}$ & & '96 & & $\begin{array}{l}\text { 1)控えI } \\
\text { 2)鋼矢板 }\end{array}$ \\
\hline 7 & 430 & 95 & 10 & 95 & 10 & 95 & 10 & $\circ 05$ & W & 05 & & & \\
\hline 8 & 112 & 99 & 10 & 99 & 10 & 99 & 10 & 95 & $\mathrm{TP}^{1)}$ & & & & 1)控え工 \\
\hline 9 & 287 & 96 & 5 & 96 & 5 & 01 & 10 & '01 & W & '01 & & & \\
\hline 40 & 230 & 204 & 10 & '04 & 10 & '04 & 10 & '04 & $\mathrm{TP}^{1)}$ & & & & 1)控えI \\
\hline & $4,930 *$ & & & & & & & & & & & & \\
\hline
\end{tabular}

ば，明らかに初期コストの安いオプション 1 が有 利である。

\section{6. 維持管理例一ストックホルム旧港 3)}

LCM システムで維持管理している港湾施設は少ない. WG31 の LCM 報告のケーススタディから， LCM システ ムを適用しているストックホルム旧港の例を紹介する。

ストックホルム市は, ストックホルム旧港 (北緯 $59^{\circ}$ $20^{\prime}$ ，東経 $18^{\circ} 04^{\prime}$ ）の岸壁（約 $7 \mathrm{~km}$ ）を管理している. 市の旧港維持管理の基本は，商業施設としての重要性は 低下したが，安全性のほか，堤防護岸，都市造景計画， 歩行者道路, 駐車場, マリーナとして岸壁を維持するこ とである．市は 1986 年〜1988 年に岸壁を調査し，以後, LCM システムを適用して定期点検, メンテナンス, 補 修対策を実施している。

（1） LCM 一初期段階

1) 背景

メンテナンス技術者が直面する典型的な事項

は，次の通り：

a）定期点検が行われていない.

b) メンテナンス計画がない.

c）メンテナンスコストに対する長期予算がな w.

d）メンテナンスに対する年間予算が少ない.

e）競合するメンテナンス工法の比較が難しい.

港運用者は，管理する港湾構造物の技術・運用 の状態およびメンテナンスコスト不足がもたらす 問題を知る必要がある。このため, 意思決定者向 けの現状説明資料が必要であり，LCM の害行に は資金の長期予算化と配分が絶対条件である.

2） LCM 組織：LCM は，経験のある技術者グルー プによって行う。

（注 $3 ： \mathrm{LCM}$ 報告の LCM 組織：メンテナンス部を 設置してコンサルタント・大学・専門家の選抜名 簿を準備し, 特別・大規模調査ではその協力を得 る. 名簿は定期的に更新する.メンテナンス部を
設置しない場合，メンテナンス・補修業務を資格 のある専門業者に請負わせる.)

3）デー夕収集とデータベース作成

4）点検 - 調査・材料試験

5）岸壁状態の技術的評価: 劣化度判定

6）点検・メンテナンス・補修データの収集：10 年 以内の所要メンテナンス対策リストを含む総合的 評価

7）意思決定プロセス：意思決定者へ提案

(2) LCM一実施段階

1） LCM の実施：岸壁の LCM は，市内の他の施設 （橋・トンネル・擁壁・階段・デッキなど）を含 む大規模 LCM システムの一部である。すなわち， 全体の LCM 予算約 13.5 百万米ドル/年に対して, 岸壁の LCM 予算はその中の 0.7 百万米ドル/年で ある. 岸壁 LCM は, 点検プログラム（10 年）, 作業プログラム $(5$ 年), 年間作業プログラム（1 年）による.

2）点検：一般点検は全岸壁を対象に毎年行うが, 詳細点検が予定される岸壁は除く，一般点検は水 面上の目視観察で，年間コストは 4,000 米ドルで ある。変位と水準調査は, 沈下, 変位, 傾斜をチ エックするために行い, 年間コストは 8,000 米ド ルである。詳細点検は，表 1 に準拠して 5 年また は 10 年ごとに行う. 詳細点検の内容は, 水面上 下の近接目視観察, 水深測量, テストピットとウ インドウ試験，コンクリート・鋼材・木材の材料 試験，荷重試験である．詳細点検デー夕に基づく 技術評価は，安全性と支持力・メンテナンスの必 要性・残存寿命の情報を与える。詳細点検プログ ラムは 2 年ごとに綿密に検討する.

3）作業プログラム：メンテナンスと補修対策を実 施するために，作業プログラム（表 2）を 5 年ご とに作成する.プログラムは詳細な毎年のプログ ラムに対する指標である。

4）打合せとコスト：LCM グループの打合せを 2 か月ごとに行い, 各構造物の水準測量・点検・補 
表 2 作業プログラム（実行）（ストックホルム旧港）

\begin{tabular}{c|c|c|c|c|c|c}
\hline 岸 壁 & \multicolumn{6}{|c}{ メンテナンス費 (千米ドル) } \\
\cline { 3 - 7 } No. & '91 & '92 & '93 & '94 & '95 & '96 \\
\hline 1 & & 135 & & & 55 & \\
\hline 2,3 & 120 & 120 & & & 65 & \\
\hline 8 & & & & 160 & 15 & \\
\hline 10 & & & & & 135 & 250 \\
\hline 11 & & 105 & 40 & & & \\
\hline 12 & & 40 & & & & \\
\hline 14 & & 105 & 345 & & & 160 \\
15 & 160 & & & 135 & 135 & \\
\hline 16 & & & 25 & 575 & & 15 \\
\hline 20 & 345 & 55 & & & & \\
\hline 31 & & & 80 & 25 & & 80 \\
\hline$X^{*}$ & 40 & 135 & 80 & 55 & 55 & 65 \\
\hline 合 計 & 665 & 695 & 570 & 950 & 460 & 570 \\
\hline$X^{*}:$ 計設
\end{tabular}

$\mathrm{X}^{*}$ : 計画, 設計, 入札, 管理

修などの問題処理結果や予算と比較した財政状態 の検討を行う． 1997 年の年間予算は以下の通りで ある.

\begin{tabular}{|c|c|}
\hline データ収集とデータベース作成 & 27,000 \\
\hline 点検·調査·材料試験 & 53,000 \\
\hline 管理・設計・入札 & 65,000 \\
\hline 建設 & 535,000 \\
\hline
\end{tabular}

7. おわりに

膨大な社会資本ストックの維持管理には, ライフサイ
クルコストを最小にする LCM システムの適用，例えば， 新設構造物については適切な防食と定期的な防食管理の 実施, 既設構造物については適切な点検・防食・補修と 定期的な防食管理の実施，が望まれる.

ストックホルム旧港の維持管理例に見られるように, LCM の実施には財政上の課題，特に長期予算の策定が 重要である.このためには, 港湾構造物の維持管理者に LCM の必要性及び経済性を十分に説明することが必要 である。しかしながら，港湾構造物の LCM はあまり行 われていないようなので，本報では，PTC-II WG31の LCM 報告から関係事項を紹介した。“港湾構造物のライ フサイクル管理”の啓蒙に参考となれば幸いである.

\section{参 考 文 献}

1）善 一章，海水腐食，防錆・防食技術便覧，産業技術开 ービスセンター, pp.121〜 134（2000）

2）善 一章, 鋼構造物の防食・補修, 環境圏の新しい海岸 工学, フジ・テクノシステム, p.1099 (1999).

3) PIANC PTC-II WG31, Life cycle management of port structures-General principles, International Navigation Association, Supplement to Bulletin no. 99, pp.1 47 (1998).

4) PIANC PTC-II WG31, Inspection, maintenance and repair of port structures, PIANC PTC-II WG31 Report-Revision 2002 (未刊).

5) PIANC PTC-II WG31 関係資料.

6) H. Klingenberg and H. Bergstrom, "Swedish Experience of Corrosion on Steel Sheet Piling Quays in the Baltic", Baltic Conference on Design, Construction and Maintenance of Harbour Structures, Swedish Geotechnical Institute, p.4 (1987).

7) C. W. Ross, Corrosion, 5 [10] 339 (1949).

8）沿岸開発技術研究センター, 港湾鋼構造物防食・補修マニ ユアル (改訂版), pp.1 371 (1997).

(2003 年 5 月 7 日受理) 